\title{
The Character Education of R.A. Kartini Perspective
}

\author{
Miftakur Rindlo \\ \{miftahridlo@gmail.com\} \\ Graduate Students of Primary School Departemen, Teacher and Training Faculty, Universitas Muria \\ Kudus, Indonesia Gondang Manis PO. BOX 53 Bae, Kudus, Central Java, Indonesia Phone (+62291) \\ 438229, Fax (+62291)437198
}

\begin{abstract}
The background in this research because of a long and endless moral crisis. To form good character, effective and appropriate methods are needed so that students easily understand and love and implement character values in everyday life. The purpose of this research is to examine the letters from R.A. Kartini about character education. This research is a type of library research because it is done in a library with the aim of analyzing the contents of the book. The methods used in this study are rational, interpretation, inductive, and analogical methods. The findings indicate that there are several methods that can be applied in an effort to shape children's character, namely exemplary methods, play methods, and methods with reading books.
\end{abstract}

Keywords: character, R.A Kartini, formation of child character

\section{Preliminary}

The moral crisis that is currently afflicting the Indonesian people seems endless. A decrease in moral quality occurs at every age level, from age children, adolescents, and adults. Their morale feels increasingly away from the noble values that have been possessed and exemplified by the founders of this nation. Values of manners, mutual respect, love for each other, help and so on are increasingly fading because they are continually eroded by the progress of the times.

The younger generation in an effort to find their identity is also getting heavier, because of the influence of outside culture that continues to invade living spaces, without a strong filter and moral and moral character, they will be easily affected by the external culture. The existence of violent attitude, uncaring attitude, narrow fanaticism and sectarian and emotional attitudes become new cultures and become part of his life. Negative behavior is an indicator of their low character. As a result, they acted anarchically, intolerantly and without any sense of humanity, so history has recorded a bad tragedy that hit football in the country, namely a supporter who died because of being beaten by other supporters.

Even more concerning, students who should have studied at school to study in order to prepare for their future and will receive the leadership baton in this country, among them there are those who are held hostage to social problems. Among the social problems that hold them hostage are drug and alcohol addiction, out-of-control teenage pregnancy, excessive reliance on child care outside the home, acceptance im morality on television and in the arts, cheating scandals and bullying of explosive violence in schools ${ }^{[1]}$.

Fights between students often occur and involve young people who in fact they are educated children and have sufficient intellectual capacity. In addition to brawls between 
students, bullying or violence in the school environment is endless. A senior student who should provide a good example actually acts intimidating and acts immoral to his juniors. At school they should be able to study calmly and comfortably, but the fear and tense atmosphere they get. This is due only to the actions of a handful of irresponsible students.

The quality of the menu shows that there is a failure in our education system in creating Indonesian people who are noble and virtuous. Because religious education and Pancasila moral education taught in schools have not succeeded in forming human beings with character. Even if we look at the material, the two subjects contain pretty good religious and moral values, and in teaching and learning activities many students experience completeness in following these two subjects. This means that the level of mastery of students in understanding the material of these two subjects is very good, but to apply the values contained in these two subjects is still far from expectations.

According to $\mathrm{Azra}^{[2]}$, the moral degradation that we are experiencing is more or less influenced by the education system that we have applied so far. The curriculum that we use is quite heavy and is only oriented to the development of mere cognitive domains. Whereas the domain of affection and psychomotor hardly received proper attention. Though the development of these two domains is very important in the formation of character and good character. The important thing and need serious attention in education is the formation of character. Indonesian as a developing country also echoes character education. Good news for observers of character education in the country manifested in the policy set forth in the National Education System Law no. 20 of 2003. In chapter 2 article 3, it is stated that the aim of national education is to develop the potential of students to become human beings who believe and devote to God, have noble character, are healthy, knowledgeable, capable, creative, independent, and become responsible and democratic citizens.

Considering the importance of character education in an effort to save the morale of the successor young generation of leadership and to advance the civilization of a nation, various thoughts emerged among educational thinkers and figures. One of them is R.A. Kartini. According to Sudarjat ${ }^{[3]}$, R A. Kartini was one of the few Indonesian women who had farreaching thoughts in their time. Critically, Kartini highlighted the role of Indonesian women who were marginalized due to cultural contractions. Kartini's struggles and thoughts included unity, nationalism and education.

Kartini's thoughts on education, had received appreciation from Arbaningsih. In his book entitled Kartini dari Sisi Lain: Melacak Pemikiran Kartini tentang Emansipasi "Bangsa”, it is stated that Kartini's thoughts are arguably far ahead, fostering character national building as a process of forming national character. The concept of character education according to Kartini requires examples of reliable and virtuous teachers ${ }^{[4]}$.

The opinions above may not be excessive, because Kartini herself said that education should not only prioritize aspects of knowledge, but character education also needs attention. In the letter sent to Mrs. R.M. Abendanon Madri, Kartini writes: "Give the Javanese education! and this education must not only develop the intelligence, but also the conscience,$[5]$.

From the fragment of the letter above it can be understood that in the view of Kartini education should not only develop intelligence of reason (aspect of knowledge), but also must pay attention to mind education (aspects of attitude). In other words, the education expected by Kartini is education that can help humans to be smart, and also help them become good humans. 
Making smart people can be easy to do, but making good people and having noble character, seems much more difficult. Thus it is very natural to say that noble character is very important for humans.

\section{Method}

This research is a type of literature research (library research). Library research is activities relating to collection data method from literature research, read, record and processing of research $^{[6]}$. According to Arikunto ${ }^{[7]}$. Literature research is research conducted by book content analyzing (content analysys). So the result of literature research is conclusion about language book style, tendency of book content, the writing system, lay-out, illustration, and others. The book using the main book "Habis Gelap Terbitlah Terang” by R.A. Kartini.

This research is also categorized as qualitative research, namely research that emphasizes that data collection is not guided by theory, but is guided by facts found and then constructed into hypotheses or theories ${ }^{[8]}$. In other words, this qualitative research emphasizes that every finding must be based on data and used to build theory. Qualitative research can also be seen as a research procedure that produces descriptive data, in the form of written or oral words from people and behaviors ${ }^{[9]}$, that can be observed in accordance with the understanding and interpretation of the researcher.

In addition to descriptive, qualitative research is also intended to obtain explanatory data, which is to provide explanations about the relationship of meaningful events, especially to the perceptions of participants ${ }^{[10]}$. So that in this study the author will describe the data and facts that have been obtained in order to be clear.

Because this research has this type and nature, the author will make every effort to collect data based on the book by R.A. Kartini by reading, studying, and reviewing her writing in depth and by interpreting the womb and giving annotations or comments on her thoughts.

\section{Results and Discussion}

\section{a. Kartini's Biography}

Raden Ajeng (R.A.) Kartini was born on April 21, 1879 (28 Rabiul Akhir 1808). She was born to a male aristocratic family R.M. Sosroningrat, son of prince Ario Tjondro Negoro IV, Regent of Demak ${ }^{[11]}$. Raden Ajeng was the title given to the Princess of the nobility before she married. When the noble daughter has married, the title will automatically change to Raden Ayu (RA).

When he was still a wedana in Mayong, R.M. Sosroningrat married Mas Ajeng (M.A.) Ngasirah. The marriage took place in 1972. At that time the age of the M.A. Ngasirah is still very young because she was only 14 years old. M.A. Ngasirah is a child from Kyai Haji Madirono, a famous religious teacher in the village of Telukawur. Aside from being a teacher, Kyai Haji Madirono is also a copra trader in the Mayong area. While her mother Nyai Hajah Siti Aminah also comes from Telukawur. Both parents of M.A. Ngasirah comes from a family of ordinary people ${ }^{[12]}$.

His marriage with R.M. Sosroningrat, Ngasirah has eight children, namely R.M. Slamet Sosroningrat, Pangeran Ario Sosrobusono, R.M. Pandji Sosrokartono, R.A. Kartini, R.A. Kardinah, R.M. Sosro Mulyono, R.A. Sumatri Sosrohardikusumo, dan R.M. Sosrorawito ${ }^{[13]}$. R.M. Pandji Sosrokartono is a brother of R.A. Kartini without being separated by another 
brother. The age difference between the two is about two years, this is one factor that causes the relationship between the two very close.

In 1875, R.M. Sosroningrat remarried a high-ranking noble daughter, Raden Ajeng Woerjan or Moerjam, Putri R.A.A. Tjitrowikromo, regent of Jepara before Sosroningrat. Based on lineage, Raden Ajeng Moerjam is located as garwo padmi (main wife or empress) R.M. Sosroningrat, while Mas Ajeng Ngasirah got the position as garwo ampil or concubine's wife. The results of his marriage with R.A. Moerjam, R.M. Sosroningrat has three children, namely R.A. Soelastri, R.A. Roekmini, dan R.A. Kartinah.

\section{b. R.A. Kartini's thoughts about character education.}

R.A. Kartini's thoughts about character education include material, methods and punishment. But in this paper the author only focuses his thoughts on methods that can be applied in character formation.

\section{Exemplary}

Exemplary or giving examples is absolutely necessary in a life. Can not a child speak a word because he imitates the words that are heard from those around him? Likewise, character building efforts must be given an example first. This is as stated by Kartini "that all needs is to take the first step, that is, for someone to provide an example. And if this is seen to have practical benefit, and can be adopted by others, than it will undoubtedly gain support" ${ }^{\text {[14] }}$.

In line with the letter above, R.A. Kartini also reminded about the importance of giving examples. The letter was written to Mrs. R. M. Abendanon Mandri on 31 December 1901.

There must be someone who sets the example we are convinced that if one has but the courage to begin, many will follow her. There must always be a beginning. One must go first to show the way, and the example must be good, each one waits for the other, no one dares to be first ${ }^{[15]}$.

More explicitly R.A. Kartini said that "there is no better sermon than setting an example, a good model to follow"[16]. What was conveyed by Kartini seemed to revive our memories, the meaning of the word "teacher". In Javanese the teacher means "iso digugu lan ditiru". This expression implies that a teacher of his words must be able to be used as a handle and all his behavior or actions must be able to be an example. The teacher must be able to provide good examples for his students, whether he is at school, at home, or where he is.

\section{Play}

Education organized by R.A. Kartini is an education for the age of children, so it is not surprising that R.A. Kartini wrote the importance of learning while playing.

We could lead the young hearts through play and help to form the young characters. During the hours when those children would be at school, we could take other little children of native chiefs here in our own neighbourhood and teach them elementary branches, handiwork and other things. All the while unperceived, we would be knockibg at the little hearts and trying to get nearer to the little souls ${ }^{[17]}$.

In another letter, R A. Kartini wants to educate children while playing, but still gets lessons and education ${ }^{[18]}$. The idea of "educating children while playing" is the same as the concept of learning while playing. This means that the learning concept is packaged in the form of a game. In other words, even though children learn while playing, they still get school lessons and character building. 


\section{Reading books}

In view of R.A. Kartini attempts to establish character in the school environment, the teacher has an important role. The existence of teachers in schools, both speech and behavior will be followed and emulated by their students. Besides the teacher, R.A. Kartini considers the importance of reading resources for education, and good reading sources will be able to educate, promote, glorify and elevate humanity ${ }^{[19]}$. The availability of educating reading books must of course be adjusted to the age level.

In another letter, R.A. Kartini also considered the importance of reading books as a foundation in character education.

R.A. Kartini writes:

How can one introduce this moral basis to adults and young adults? I think through appropriate reading matter. One should publish reading material that should include leisure reading (so that they would be eagerly read) but always with an educational aim $^{[20]}$.

In view of R.A. Kartini, character education can be pursued through the availability of significant reading books. Of course, the right reading for children's consumption is educational reading books, both in the form of books or magazines.

The fact that in the book there is a lot of information and knowledge needed by students, the book has a very big role. Primarily as a means to advance the nation's civilization. About the importance of reading books at school, R.A. Kartini not only wrote it in a letter, but confirmed it on an Education note. In the memorandum written in January 1903, related to the importance of reading books found in several paragraphs, namely:

A further means of education from which much benefit can be expected is reading material. It would be an excellent additional source of instruction. The Javanese has practically no reading material, what he does have are some epie poems and moral tales which even then are only available to very few, since almost all of them are hand written, they represent heirlooms passed down from generation to generation and many of them are written allegorically and in a language which is unintelligible to most people ${ }^{[21]}$.

In the paragraph above, R.A. Kartini had the assumption that the availability of reading books in schools helped support education. These books can be in the form of poetry books and reading books that contain moral education. In order for readers to be easy to understand and capture the messages contained in these books, it should be written in a simple, fresh, and interesting language to read.

\section{c. Contextualization of Thoughts R.A. Kartini About Character Education in Learning}

\section{Exemplary}

In character education, capital or modeling is a commonly used strategy. Even according to Gunawan ${ }^{[22]}$, exemplary is a more effective and efficient method. This method is said to be effective because the nature of students (especially students at the age of primary and secondary education) generally tends to imitate (imitate) the teacher or educator. And psychologically, a child does have a tendency to imitate the figure (model) in the surrounding environment. This method is considered efficient because it does not require a lot of money to make a display, but it is enough examples or good examples from the teacher.

If students find the model closer to be used as a role model, it will be easier and more effective for character education. Students need a real example, not an example in fantasy. Therefore, success in character education is strongly influenced by the figure being modeled by the child.

The model that can give a big influence on students is the closest model for students. The model can come from the family environment and school environment. The model of the 
family environment can be obtained by children through examples given by father, mother and other family members. While the model of the school environment is obtained by the child through the example given by the teacher and other education personnel in the educational institution.

According to Zubaedi ${ }^{[23]}$, to be able to use the exemplary method, there are two conditions that must be met. First the teacher or parent must act as a good model for students or children. Both children must emulate famous people of noble character, for example the prophet Muhammad. Thus, parents and teachers have a strategic role in providing models or role models to children. All sayings and actions of parents and teachers must be maintained. Speech from parents and teachers must contain wisdom and all their actions must be trustworthy. Through this example, it means parents and teachers have instilled positive values in their children's hearts.

Exemplary methods as one of the strategies in an effort to shape students' character must be supported by a conducive environment. In the family environment parents must be able to play a role as a good model, while in the school environment teachers and all education personnel must be able to act as a good model too "legitimized, modeled, and reinforced by school and teachers"[24].

\section{Play}

Playing is a variety of forms of activities that give satisfaction to children that are nonserious, flexible, and even toys contained in activities and imaginative sex is transformed commensurate with the world of adults, so playing has an important meaning for the growth of children $^{[25]}$.

Regarding the importance of playing, a prominent thinker, Al Ghazali, emphasized that students were allowed to play with light games and the game did not exhaust them after class. If children are prohibited from playing and forced to keep learning, then their hearts will die, their intelligence will be dull and they will feel bitterness with this life ${ }^{[26]}$.

What was conveyed by Al Ghazali is still general, because it only provides opportunities for children to play when they are tired of participating in learning activities. So giving the opportunity to rest rather than playing when in learning. In other words at rest, children can play for a while so that their minds can refresh again while following the lesson.

According to Hamdani ${ }^{[27]}$, teachers can create ways of learning while playing. This method can be done by the teacher when the child reaches saturation in learning activities. Admittedly, this method really demands the creativity of the teacher to create a fun game. Do not let the game in learning whose purpose is to make students happy, it becomes burdensome for them.

Games in learning if applied properly will have a function that is maintaining balance, anticipating the roles that will be lived in the future, perfecting skills with other children ${ }^{[28]}$. In the game needed to maintain cohesiveness is not his greatness, especially in team games.

Through the method of playing, it is expected that children will find noble values in the game. The type of game should be adjusted to the age level and the level of development of children's knowledge, so that the game in fostering character values in children. The character values in the game are cooperation, discipline, responsibility, togetherness, tolerance, never giving up, hard work, honesty/ sportsmanship and concentration training.

\section{Reading books}

According to R.A. Kartini, the availability of reading books in an effort to shape children's character is very important. There are many benefits obtained from reading books, one of 
which is to be able to add insight or knowledge. If this effort is carried out, then as a consequence the school must educate, not a book containing only news about theft, fire and robbery. However, the author does not get the thought of a character who conveys his ideas about the method of reading. However, we cannot justify that this method does not have contextualization of character education.

According to Ilyas [29], the exemplary method can be applied in two forms, namely directly and indirectly. The purpose of the exemplary method directly is that a teacher gives a good example to students, while the indirect method means that educators set an example for their students by telling stories or students are told to read for themselves about good example stories, including can be a history of the prophets, stories of great people, heroes and martyrs.

Through the method of story, students are expected to be able to make these characters as idols in their lives and ultimately want to emulate the spirit and noble character of these figures. This is very important, so that children no longer only know the imported Heroes they watch through glass screens such as Masha, Shiva, Spongebob and Doraemon, as well as Upin and Ipin, but children also know national heroes who defend their people from the invaders, the figures who contributed in the surrounding environment, knew the prophets, the trustees or people who had other noble characters.

Thus the availability of reading books that are used as methods in an effort to form characters implicitly is included in the exemplary method. Exemplary given by educators indirectly, namely when children are told to read their own reading books about heroes, other great figures or Nusantara stories.

While Suparno ${ }^{[30]}$, said that the formation and character development of a child is influenced by family (parents), teachers, friends or groups, school environment, community, reading books (media, television, video, internet, gadgets), and religion. Many children develop their character because of the contents of the books they read. The book he has read since school has an influence and inspiration for his life.

The provision of character-building reading books can follow the rules set out in curriculum guidelines or from teacher initiatives based on certain considerations ${ }^{[31]}$. As an input material that should be considered by the teacher in the provision of reading books is educational reading books. The books can be in the form of history about the nation (the country), the story of the heroes' struggles, the biographies of influential people, Nusantara stories, or motivational books.

It needs to be reiterated that, success in character education cannot be separated from the use of the right method. With the right method, students are expected to be able to easily digest or understand and love the character values taught. After that, students are expected to grow their awareness to internalize the character values that have been taught in their daily lives.

Nevertheless, character education clearly requires commitment from all parties, carried out intensively, and synergistically. The involvement of all components of education, both parents, schools, teachers, and the community needs to be utilized optimally in the effort to grow the character of children. This is a necessity because the enculturation process is ongoing. 


\section{Conclusion}

From the series of discussions and some of the descriptions above, the methods that can be applied in an effort to shape the character of students according to R.A. Kartini is an exemplary method, playing method, and method by providing reading books. These three methods can be applied in education in the family environment and in education in the school environment.

Contextualization of exemplary methods can be applied in character education through models that can be used as examples by students. The model that can give a big influence on students is the closest model for students. The play method should be adjusted to the age level and the level of development of the child's knowledge. Through the method of playing, it is expected that children will find noble values in the game, such as cooperation, discipline, responsibility, togetherness, tolerance, never giving up, hard work, and honesty. Formation and character development of a child can be influenced by family (parents), teacher, friend or group, school environment, community or environment, and reading books. Therefore at school should provide educational reading books.

\section{References}

[1] Nelson, Jack L., Palonsky, Stuart B., and McCarthy. Critical Issues in Education: Dialogues an Dialectics. New York: McGraw-Hill. pp. 241 (2012)

[2] Azra, Azyumardi. Paradigma Baru Pendidikan Nasional: Rekonstruksi dan Demokratisasi. Jakarta: PT. Kompas Media Nusantara. pp. 21 (2002)

[3] Sudrajat. Kartini: Perjuangan dan Pemikirannya. Jurnal Mozaik. Vol. 2, No. 2, Universitas Negeri Yogyakarta. pp. 3 (2007)

[4] Arbaningsih, Dri. Kartini dari Sisi Lain: Melacak Pemikiran Kartini tentang Emansipasi "Bangsa". Jakarta: Buku Kompas. pp. 125 (2005)

[5] Cote, Joost. Kartini The Complete Writings 1889 - 1904. Clayton, Victoria, Australia: Monash University. pp. 307 (2014)

[6] Zed, Mestika. Metode Penelitian Kepustakaan. Jakarta: Yayasan Pustaka Obor Indonesia. pp. 3 (2018)

[7] Arikunto, Suharsimi. Prosedur Penelitian: Suatu Pendekatan Praktek. Jakarta: Rineka Cipta. pp. 16 (2010)

[8] Sugiono. Memahami Penelitian Kualitatif. Bandung: Alfabeta. pp. 3 (2016)

[9] Moleong, Lexy J. Metodologi Penelitian Kualitatif. Bandung: Remaja Rosdakarya. pp. 6 (2017)

[10] Sukmadinata, Nana Syodih. Metode Penelitian Pendidikan. Bandung: Remaja Rosdakarya. pp. 60 (2010)

[11] Soeroto, Sitisoemandari. Kartini, Sebuah Biografi. Jakarta: Gunung Agung. pp. 31 (1983)

[12] Ibid. pp. 13 (1983)

[13] Ibid. pp. 10 (1983)

[14] Cote, Joost. Kartini The Complete Writings 1889 - 1904. Clayton, Victoria, Australia: Monash University. pp. 225 (2014)

[15] Symmers, Agnes Louise. Letters of a Javanese Princess. London: Duckworth \& Co. pp. $149(1921)$

[16] Cote, Joost. Op. Cit. pp. 613 (2014) 
[17] Symmers, Agnes Louise. Letters of a Javanese Princess. London: Duckworth \& Co. pp. 259 (1921)

[18] Cote, Joost. Op. Cit. pp. 563 (2014)

[19] Ibid.pp. 470 (2014)

[20] Ibid. pp. 563 (2014)

[21] Ibid.pp. $815-816(2014)$

[22] Gunawan, Heri. Pendidikan Karakter: Konsep dan Implementasi. Bandung: Alfabeta. pp. 91 (2017)

[23] Zubaedi. Desain Pendidikan Karakter: Konsepsi dan Aplikasinya dalam Lembaga Pendidikan. Jakarta: Kencana. pp. 236 (2015)

[24] Agboola, Alex and Tsai, Kaun Chen. Bring Character Education into Classroom. European Journal of Educational Reseach. Vol. 1, No.2 pp. 166 (2012)

[25] Moeslichatun. Metode Pengajaran di Taman Kanak-kanak. Jakarta: Rineka Cipta. pp. 24 (2004)

[26] Rohani, Ahmad. Pengelolaan Pengajaran. Jakarta: Rineka Cipta pp. 30 - 31 (2004)

[27] Hamdani. Strategi Belajar Mengajar. Bandung: Pustaka Setia. pp. 111 (2011)

[28] Moeslichatun. Op. Cit. pp. 34 - 36 (2004)

[29] Ilyas, Asnelly. Mendambakan Anak Shaleh: Prinsip-prinsip Pendidikan Anak dalam Islam. Bandung: Al-Bayan. pp. 39 - 40 (1995)

[30] Suparno SJ, Paul. Pendidikan Karakter di Sekolah: Sebuah Pengantar Umum. Yogyakarta: Kanisius. pp. 65 - 75 (2015)

[31] Hamalik, Oemar. Kurikulum dan Pembelajaran. Jakarta: Bumi Aksara pp. 68 (2011) 